\title{
PENAMBAHAN TEPUNG MAGGOT PADA PELET TEPUNG KOMERSIL TERHADAP PERTUMBUHAN BENIH IKAN PATIN Pangasius hypophthalmus
}

\section{Addition of maggot flour in commercial flour pellets on growth of Pangasius hypophthalmus fingerling}

\author{
Rahma Mulyani ${ }^{1}$, Rangga Bayu Kusuma Haris ${ }^{2 *}$ \\ ${ }^{1}$ Program Studi Budidaya Ikan Fakultas Perikanan dan Kelautan \\ Universitas PGRI Palembang \\ ${ }^{2}$ Politeknik Kelautan dan Perikanan Dumai
}

Corresponding author: ranggabkh@gmail.com

\begin{abstract}
ABSTRAK
Potensi maggot Chrysomya megacephala sebagai bahan alternatif sebagai sumber protein dapat dimaanfaatkan untuk pakan benih ikan patin Pangasius hypophthalmus. Penelitian ini dilakukan selama 2 bulan yang bertujuan untuk mengetahui laju pertumbuhan dan kelagsungan hidup benih ikan patin yang diberi pakan dengan tambahan tepung maggot dengan berbagai perlakuan yaitu perlakuan A pelet tepung (100), perlakuan B pelet dengan tepung maggot (75:25), perlakuan $C$ pelet dengan tepung Maggot (50:50), dan perlakuan D tepung maggot (100). Hasil pengamatan menunjukkan penambahan tepung magot pada pakan menunjukkan hasil pertumbuhan berat tertinggi sebesar $\mathrm{C} 2,91 \mathrm{~g}$ dan terendah pada perlakuan D sebesar 1,99 g sedangkan pertumbuhan Panjang tertinggi terdapat pada perlakuan $C$ sebesar 4,67, untuk kelangsungan hidup benih ikan patin yang memberikan nilai tertinggi sebebsar 93,3\% sehingga hasil analisis menunjukkan perlakuan B dan C berbeda nayata dengan kontrol.
\end{abstract}

Kata kunci: Maggot, benih ikan patin, pakan, pertumbuhan.

\begin{abstract}
The potential of maggot Chrysomya megacephala as an alternative material as a source of protein can be utilized as feed for Pangasius hypophthalmus fingerling. This study was conducted for 2 months which aims to determine the growth rate and survival of Pangasius hypophthalmus fed with additional maggot flour with various treatments, namely treatment A pellet flour (100), treatment B pellet with maggot flour (75:25), treatment $C$ pellet with Maggot flour (50:50), and treatment $D$ with maggot flour (100). The results showed that the addition of magot flour to the feed for Pangasius hypophthalmus fingerling showed the highest weight growth of C $2.91 \mathrm{~g}$ and the lowest in treatment D of $1.99 \mathrm{~g}$ while the highest length growth was found in treatment $C$ of 4.67, to develop live Pangasius hypophthalmus fingerling which provide the highest value of $93.3 \%$ so that the results of the analysis showed that treatment $B$ and $C$ were significantly different from the control.
\end{abstract}

Keywords: Maggot, Pangasius fingerling, feeds, growth.

\section{PENDAHULUAN}

Prospek pengembangan akuakultur ikan patin (Pangasius hypophthalmus) di Indonesia terus mengalami peningkatan disetiap tahun. Peningkatan produksi ikan patin pada tahun 2015 sebesar 339.069 ton menjadi 437.110 ton pada tahun 2016. Produksi ikan patin nasional pada tahun 2019 akan ditargetkan 1 juta ton lebih (KKP, 2016). Salah satu upaya yang 
dilakukan adalah melalui ketersediaan benih secara berkesinambungan sehingga dapat berkembang dengan kemajuan ilmu pengetahuan dan teknologi serta teknik budidaya ikan yang telah banyak dikuasai.

Pakan merupakan salah satu komponen yang sangat menentukan koefisien teknis budidaya (efisiensi pakan, laju pertumbuhan dan kelangsungan hidup). Menurut Priyadi (2008), dalam usaha budidaya ikan biaya pakan sangat mempengaruhi biaya produksi. Biaya pakan ikan menempati biaya produksi tertinggi dalam kegiatan budidaya yaitu 70$89 \%$ dari total biaya produksi. Biaya pakan ini dapat ditekan dengan mencari bahan alternatif yang memiliki kandungan protein yang tinggi dan mudah didapat. Salah satu bahan pakan alternatif yang dapat digunakan sebagai sumber protein hewani adalah maggot yang dapat dimanfaatkan sebagai bahan baku pakan ikan.

Menurut Indramawan Kandungan protein maggot lebih tinggi dari pada kandungan pakan komersil yaitu berkisar antara $20-25 \%$. Namun Berdasarkan hasil proksimat yang telah dilakukan oleh Azir et al., (2017) maggot memiliki kandungan protein yang tinggi yaitu berkisar antara $25,22 \%$ - 41,22 \% . Kandungan protein yang terdapat pada maggot tersebut tergolong relatif tinggi dan sangat potensial sebagai pakan tambahan untuk pembesaran ikan konsumsi.

Maggot atau belatung ini juga mengandung antimikroba dan anti jamur, sehingga apabila dikonsumsi oleh ikan, maka akan menyebabkan ketahan terhadap penyakit yang disebabkan oleh bakteria dan jamur tersebut (Indarmawan, 2014). Selain itu maggot juga memiliki sebuah organ penyimpanan yang disebut sebagai trophocytes yang berfungsi sebagai penyimpanan kandungan nutrient yang terdapat pada media kultur yang dimakannya (Subamia, 2010). Oleh sebab itu perlu dilakukan kajian mengenai efek penambahan tepung maggot terhadap benih ikan patin. Penelitian ini bertujuan untuk menganalisis tentang penambahan tepung maggot pakan terhadap pertumbuhan benih dan kelangsungan hidup ikan patin.

\section{METODE PENELITIAN}

Penelitian ini telah dilaksanakan pada bulan September - Oktober Tahun 2019. Adapun penelitian yang berlokasi di kampus C Fakultas Perikanan Universitas PGRI Palembang. Jalan Sakti Wiranata Kelurahan Srimulya Kecamatan Sematang Borang RT. 08 RW. 02 Palembang.

Penelitian ini dilaksanakan dengan menggunakan Rancangan Acak lengkap (RAL) dengan menggunakan 4 perlakuan dan masing - masing diulang sebanyak 3 kali dengan jumlah benih Ikan Patin sebanyak 360 ekor, dengan rata-rata panjang kisaran 2-3 cm dengan masingmasing akuarium berukuran $30 \times 30 \times 30 \mathrm{~cm}$ sebanyak 20 ekor. Adapun perlakuannya adalah sebagai berikut:

A : pelet tepung (100)

$\mathrm{B}$ : pelet dengan tepung maggot $(75: 25)$

C : pelet dengan tepung Maggot (50:50)

$\mathrm{D}$ : tepung maggot (100)

Hewan uji masing-masing perlakukan dipelaharan selama dua bulan dengan memberikan pakan secara ad-satiation. Pakan yang diberikan pada benih ikan patin dalam penelitian ini dilakukan dengan cara mencampur pelet dengan tepung Maggot dengan perbandingan yang telah ditentukan dalam kegiatan penelitian dengan menambahkan seprotan sedikit air hingga pakan dapat dibentuk gumpalan.

\section{Parameter yang Diamati}

\section{Pertumbuhan Berat}

Pertumbuhan ikan patin selama penelitian dihitung berdasarkan selisih antara rataan bobot tubuh ikan patin pada awal penelitian dengan rataan bobot tubuh ikan patin pada akhir penelitian dengan menggunakan rumus Effendie (1979), yaitu sebagai berikut :

$$
\mathrm{GW}=\mathrm{Wt}-\mathrm{Wo}_{0}
$$


Keterangan :

$\mathrm{Gw}=$ Pertambahan bobot $(\mathrm{g})$

$\mathrm{Wt}=$ Bobot rerata pada akhir penelitian $(\mathrm{g})$

$\mathrm{Wo}=$ Bobot rerata pada awal penelitian $(\mathrm{g})$

\section{Pertumbuhan Panjang}

Pertumbuhan mutlak jumlah panjang Ikan dapat diketahui dengan menggunakan rumus yang dikemukakan Effendi (1979) sebagai berikut:

$\mathrm{Pm}=\mathrm{Pt}-\mathrm{Po}$

Keterangan :

Pm : Pertambahan panjang $(\mathrm{cm})$

Pt : Rerata panjang pada akhir $(\mathrm{cm})$

Po : Rerata panjang pada awal $(\mathrm{cm})$

Kelangsungan Hidup (SR)

Pengamatan kelangsungan hidup dilakukan setiap hari dengan mencatat jumlah Ikan yang mati beserta penyebabnya. Untuk mengetahui tingkat (Survival Rate) dengan menggunakan rumus Effendie (1997) sebagai berikut:

$$
\mathrm{SR}=\frac{N t}{N o} \times 100 \%
$$

Keterangan :

SR : Tingkat kelangsungan hidup (\%)

$\mathrm{Nt}$ : Jumlah ikan hidup akhir (ekor)

No : Jumlah ikan hidup awal (ekor)

\section{Kualitas Air}

Parameter kualitas air yang diamati dalam penelitian ini adalah kadar oksigen terlarut (DO), $\mathrm{pH}$, suhu, dan ammonia.

\section{Analisis Data}

Data hasil penelitian yang diperoleh yaitu Pertumbuhan berat, Pertumbuhan panjang, dan Kelangsungan hidup dapat dianalisa menggunakan sidik ragam Analisis Of Varience (ANOVA). Analisis sidik ragam Analisis of Varience (ANOVA) dapat dilihat pada Tabel 1 yaitu sebagai berikut:

Tabel 1. Analisis Sidik Ragam Analisis Of Varience (ANOVA)

\begin{tabular}{llcccc}
$\begin{array}{c}\text { Sumber } \\
\text { keragaman } \\
\text { (SK) }\end{array}$ & $\begin{array}{c}\text { Derajat Bebas } \\
\text { (DB) }\end{array}$ & $\begin{array}{c}\text { Jumlah } \\
\text { Kuadrat } \\
(\text { JK) }\end{array}$ & $\begin{array}{c}\text { Kuadrat } \\
\text { Tengah } \\
(\text { KT) }\end{array}$ & F.hitung & \multicolumn{2}{c}{ F Tabel } \\
$\mathbf{5 \%}$ & $\mathbf{1 \%}$ \\
\hline Perlakuan & $\mathrm{t}-1$ & $\mathrm{JKP}$ & $\mathrm{JKP} / \mathrm{V}_{1}$ & $\mathrm{KTP} / \mathrm{KTG}$ & $\left(\mathrm{V}_{1}, \mathrm{~V}_{2}\right)$ \\
Galat & $(\mathrm{rt}-1)-(\mathrm{t}-1)=\mathrm{V}_{2}$ & $\mathrm{JKG}$ & $\mathrm{JKG} / \mathrm{V}_{2}$ & & \\
\hline Total & $\mathrm{rt}-1$ & $\mathrm{JKT}$ & & & \\
\hline
\end{tabular}

Sumber : Hanafiah (2002)

Signifikansi pada analisis
keragaman dilakukan
membandingkan $\mathrm{F}$ hitung dan $\mathrm{F}$ tabel pada uji taraf $5 \%$ dengan dasar perbandingan sebagai berikut :

1. Jika F hitung $\leq$ F-tabel $5 \%$ maka dinyatakan faktor perlakuan memberikan pengaruh tidak nyata dan diberi tanda ${ }^{\text {tn }}$.

2. Jika $\mathrm{F}$ hitung $>\mathrm{F}$-tabel $5 \%$ dan $\mathrm{F}$ hitung $\leq$ dengan F-tabel 1\%, maka dinyatakan faktor perlakuan memberikan pengaruh nyata dan diberi tanda $*$.

3. Jika F hitung lebih besar dari F-tabel $1 \%$, maka perlakuan berbeda sangat nyata terhadap data hasil pengamatan dan diberi tan $* *$.

Jika hasil uji pada (ANOVA) perlakuan dalam penelitian memberikan pengaruh yang nyata, maka untuk mengetahui pengaruh perbedaan yang nyata antara perlakuan akan dilakukan uji lanjut dengan menggunakan uji lanjut yang akan ditentukan oleh Koefisien keragaman (KK). Adapun uji lanjut tersebut adalah Uji Beda Nyata Jujur (BNJ) digunakan apabila $\mathrm{F}$ hitung tidak berbeda nyata dan dapat digunakan untuk membandingkan semua pasangan perlakuan yang ada, dengan Koefisienan 
Keragaman (KK) 5-10\%. Uji beda nyata terkecil (BNT) digunakan apabila Fhitung nyata dan tidak dianjurkan utuk membandingkan semua pasang perlakuan yang mungkin, dengan koefisien keragaman (KK) 5\%. Uji duncan digunakan apabila Fhitung nyata tetapi dapat digunakan untuk membandingkan semua pasang perlakuan yang ada, dengan koefisienan keragaman (KK) $10 \%$.

\section{HASIL DAN PEMBAHASAN Pertumbuhan}

Pertumbuhan Panjang

Data hasil penelitian pertumbuhan panjang rata-rata benih patin (Pangasius hypopthalmus) pada masing-masing perlakuan dapat dilihat pada Tabel 2 dan Gambar 1.

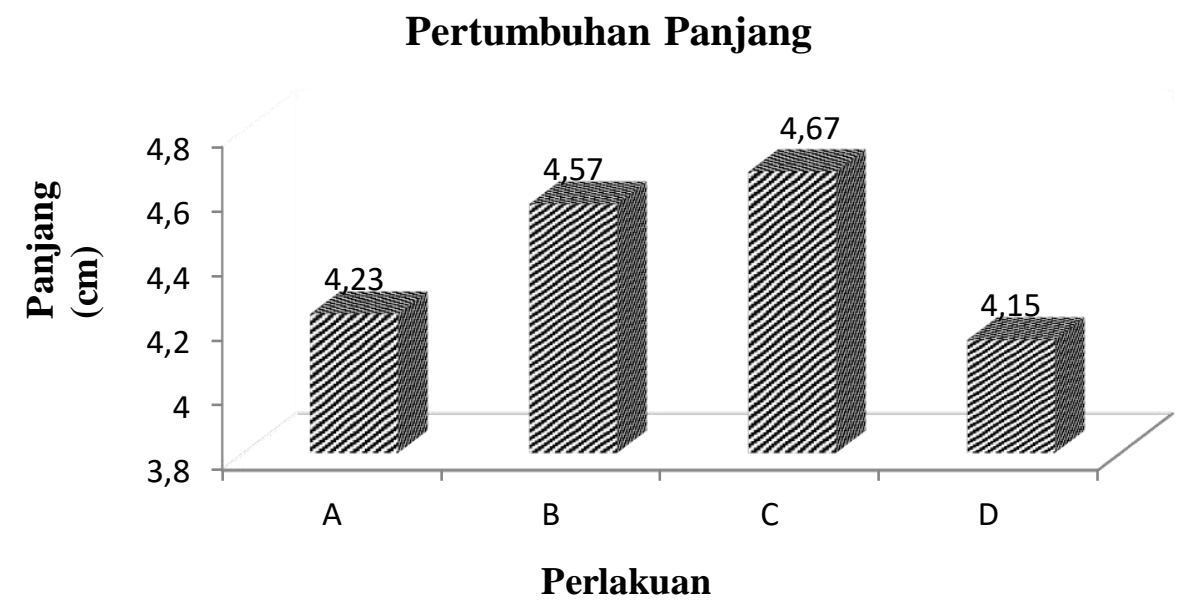

Gambar 1. Rata-rata Pertumbuhan Panjang Benih Ikan Patin.

Dari hasil penelitian diperoleh data rata-rata pertumbuhan benih ikan patin pada setiap perlakukan menunjukkan bahwa perlakuan $\mathrm{C}$ lebih tinggi dibandingkan dengan perlakukan yang lain yaitu sebesar 4,67 cm. Sedangkan pada perlakuan D terlihat bahwa pertumbuhannya paling rendah yaitu sebesar 4,15 cm. Data tersebut selanjutnya dianalisis secara statistik menggunakan analisis sidik ragam yang ditampilkan pada tabel 2.

Tabel 2. Hasil Analisis Sidik Ragam Pertumbuhan Panjang Benih Ikan Patin

\begin{tabular}{|c|c|c|c|c|c|c|}
\hline \multirow[t]{2}{*}{ SK } & \multirow[t]{2}{*}{ DB } & \multirow[t]{2}{*}{ JK } & \multirow[t]{2}{*}{ KT } & \multirow[t]{2}{*}{ Fhitung } & \multicolumn{2}{|l|}{ Ftabel } \\
\hline & & & & & $5 \%$ & $1 \%$ \\
\hline Perlakuan & 3 & 0,579 & 0,193 & $14,095^{*}$ & 4,07 & 7,59 \\
\hline Galat & 8 & 0,110 & 0,014 & & & \\
\hline Total & 11 & 0,689 & & & & \\
\hline
\end{tabular}

Bedasarkan pada tabel 2, hasil analisis sidik ragam menunjukkan pertumbuhan panjang benih ikan patin menunjukkan kombinasi pemberian tepung maggot berpengaruh nyata yaitu dapat dilihat pada nilai $\mathrm{F}$ hitung $>$ dari $\mathrm{F}$ tabel 14,09 $>4,07$ pada taraf uji $5 \%$.

Pada perlakuan $\mathrm{C}$ dengan penambahan tepung maggot sebanyak $50 \%$ dan tepung pellet sebanyak 50\% menghasilkan rata-rata pertumbuhan panjang benih ikan patin sebesar $4,67 \mathrm{~cm}$, dimana perlakukan tersebut berbeda nyata dengan perlakuan A sebesar $4,23 \mathrm{~cm}$ dan perlakuan D sebesar $4,15 \mathrm{~cm}$. Hal tersebut diduga bahwa ikan patin tersebut dapat memanfaatkan nutrisi yang terdapat di pakan dengan baik terutama kebutuhan 
proteinnya, dimana ikan mengkonsumsi protein untuk mendapatkan sumber asamasam amino yang akan digunakan untuk pemeliharaan sel-sel tubuh, metaboliame, pertumbuhan dan kegiatan reproduksi (Zainuddin dkk., 2012). Hal tersebut juga disampaikan dalam penelitian Mutjiman (2012) yang menyatakan bahwa jumlah makanan dan kandungan gizi yang seimbang dengan kebutuhan ikan merupakan hal penting bagi ikan untuk proses metabolisme dan pertumbuhan.

Pertumbuhan Berat

Data hasil pertumbuhan berat rata-rata benih Ikan patin (Pangasius hyphophthalmus) selama penelitian dapat dilihat pada gambar 2 .

\section{Pertumbuhan Berat}

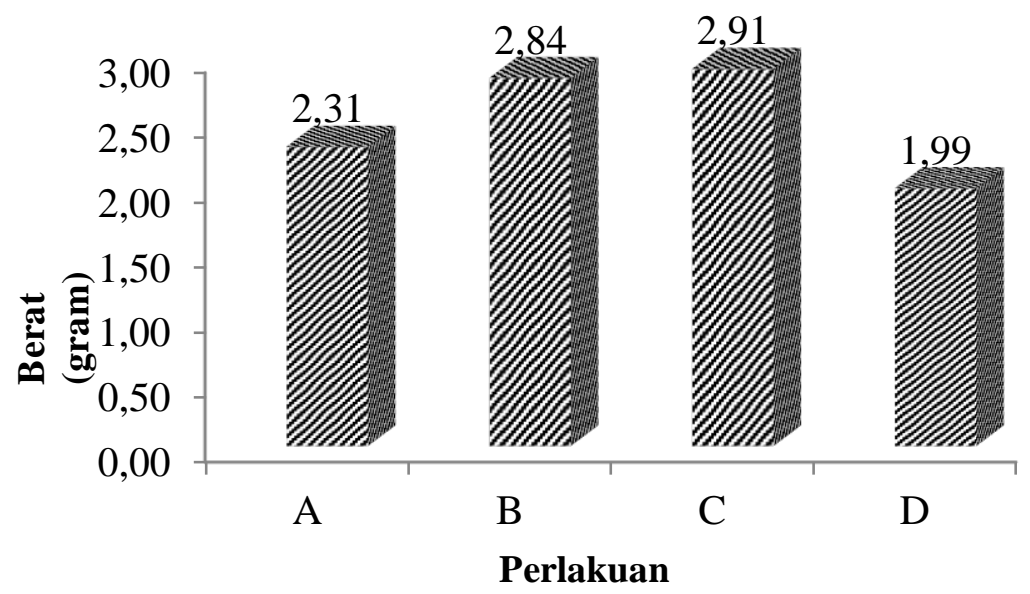

Gambar 2. Rata-rata Pertumbuhan Berat (gr) Benih Ikan Patin

Berdasarkan hasil penelitian yang terdapat pada Tabel 4 dan Gambar 2 diatas nilai pertumbuhan berat tertinggi terdapat pada perlakuan $\mathrm{C}$ sebesar 2,91 gram, diikuti dengan perlakuan B sebesar 2,84 gram lalu perlakuan A sebesar 2,31 gram serta yang terendah terdapat pada perlakuan D sebesar 1,99 gram.
Berdasarkan hasil penelitian didapat pertumbuhan berat terhadap pertumbuhan ikan patin (Pangasius hypopthhalmus) diperoleh hasil analisis sidik ragam Analisis Of Varience (ANOVA) penambahan tepung maggot pada pakan terhadap pertumbuhan dan kelangsungan hidup ikan patin (Pangasius hypophthalmus) dapat dilihat pada Tabel 3.

Tabel 3. Hasil Ansira Pertumbuhan Berat Ikan Patin (Pangasius hypophthalmus)

\begin{tabular}{lrrrrrr}
\multicolumn{1}{c}{ SK } & DB & JK & KT & Fhitung & \multicolumn{2}{c}{ Ftabel } \\
\cline { 6 - 7 } & & & & & $\mathbf{5 \%}$ & $\mathbf{1 \%}$ \\
\hline Perlakuan & 3 & 1,730 & 0,577 & 2,682 & 4,07 & 7,59 \\
Galat & 8 & 1,720 & 0,215 & & & \\
\hline Total & 11 & 3,451 & & & & \\
\hline
\end{tabular}

KK : 18,4516

Data hasil analisis sidik ragam pertumbuhan berat Ikan patin (Pangasius hypophthalmus) dengan perlakuan penambahan tepung maggot terhadap pertumbuhan berat (Tabel 3) menunjukan hasil $\mathrm{F}_{\text {hitung }}<\mathrm{F}_{\text {tabel }}$ yaitu 2,682 $<4,07$ pada 
taraf uji 5\% yang berarti menunjukkan bahwa penambahan tepung maggot tidak berpengaruh nyata terhadap pertumbuhan berat ikan patin (Pangasius hypophthalmus) dengan nilai Koefisien Keragaman sebesar 18,4516 maka hasil yang diperoleh dalam penelitian ini tidak perlu dilakukan uji lanjut.

Hasil menunnjukkan bahwa perlakuan $\mathrm{C}$ berpengaruh nyata terhadap perlakuan A dan perlakukan D, sedangkan perlakuan $\mathrm{C}$ tidak berpengaruh nyata terhadap perlkuan B. Pada perlakuan C didapatkan hasil pertumbuhan berat sebesar 2,91 gram dan perlakuan D memberikan hasil pertumbuhan berat yang paling rendah. Rendahnya hasil pertumbuhan berat perlakuan $\mathrm{D}$, diduga bahwa kecukupan dan keseimbangan nutrisi yang ada dalam pakan tidak terpenuhi sehingga menyebabkan terhambatnya petumbuhan berat pada benih, karena pakan yang baik adalah pakan yang nutrisinya seimbang atau cukup, baik dari segi protein, lemak, karbohidrat, vitamin dan mineral. Karena keberhasilan kegiatan pemeliharaan ikan ataupun budidaya ikan dapat dilihat dari hasil kelangsungan hidup yang tinggi (Efianda et al., 2020). Yulisman \& Sasanti (2012); Yuliansyah et al., (2021) memaparkan bahwa keseimbangan antara komponen asam amino dan protein dalam pakan merupakan faktor yang mempengaruhi pertumbuhan dan performa kesehatan ikan. Sedangkan pertumbuhan berat tertinggi pada perlakuan $\mathrm{C}$ diduga bahwa ikan mempu memanfaatkan pakan yang diberikan dengan baik. Menurut Wijayanti et al., (2014) memaparkan bahwa pakan yang terdapat dua sumber protein atau lebih akan memberikan performa pertumbuhan yang lebih baik terhadap ikan yang dipelihara.

\section{Kelangsungan Hidup}

Hasil pengamatan kelangsungan hidup ikan patin (Pangasius hypophthalmus) pada masing-masing perlakuan disajikan secara lengkap terdapat pada Gambar 3.

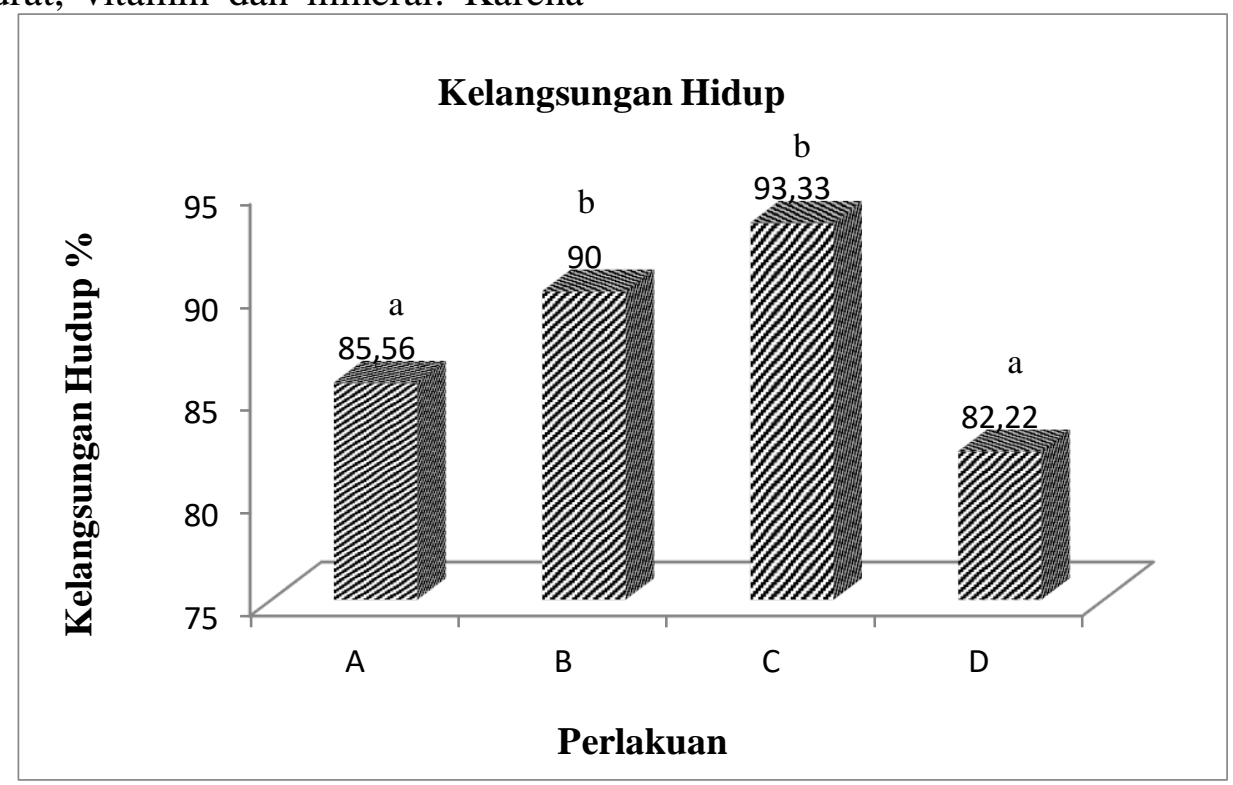

Gambar 3. Grafik Tingkat Kelangsungan Hidup Ikan Patin

Berdasarkan gambar 3 menunjukkan nilai kelangsungan hidup tertinggi terdapat perlakuan C yaitu sebesar $93,33 \%$, diikuti perlakuan B dengan nilai kelangsungan hidup 90\% dan perlauan A sebesar 85,56\%. Sedangkan nilai kelangsungan hidup terendah terdapat pada perlakuan D yaitu sebesar 82,22 \%. Perhitungan kelangsungan hidup benih ikan patin yang diberikan berbakai perlakuan diperoleh hasil data analisis ANOVA yang disajikan pada tabel 4 berikut. 
Tabel 4. Hasil Analisis ANOVA Kelangsungan Hidup Ikan Patin

\begin{tabular}{lrccrrr}
\multicolumn{1}{c}{ SK } & \multirow{2}{*}{ DB } & JK & KT & Fhitung & \multicolumn{2}{c}{ F tabel } \\
\cline { 6 - 7 } Perlakuan & 3 & 214,815 & 71,605 & 1,886 & 4,07 & 7,59 \\
Galat & 8 & 303,704 & 37,963 & & & \\
\hline Total & 11 & 518,519 & & & & \\
\hline KK : 7,019327 & & & & & &
\end{tabular}

Hasil analisis ANOVA kelangsungan hidup Ikan patin (Pangasius hypophthalmus) dengan penambahan tepung maggot menunjukkan hasil $\mathrm{F}_{\text {hitung }}<$ $\mathrm{F}_{\text {tabel }}$ pada taraf uji 5\% yang berarti bahwa tidak berpengaruh nyata dengan nilai koefisien keragaman (KK) sebesar 7,019327. Hasil analisis ANOVA kelangsungan hidup Ikan patin siam (Pangasius hypophthalmus) dengan penambahan tepung maggot menunjukkan hasil $\mathrm{F}_{\text {hitung }}>\mathrm{F}_{\text {tabel }}$ pada taraf uji $5 \%$ yang berarti bahwa berpengaruh nyata dengan nilai koefisien keragaman (KK) sebesar 2,65714 maka dilakukan dengan uji BNT yang dapat dilihat pada Tabel 3 .

Berdasarkan pada Gambar 3 bahwa tanpa penambahan tepung maggot pada pakan di perlakuan A menghasilkan kelangsungan hidup $85,56 \%$ tidak berpengaruh nyata pada perlakuan D sebesar $82,22 \%$, namun berngaruh nyata pada perlakuan $\mathrm{B}$ dan $\mathrm{C}$ dimana masingmasing nilai kelangsungan hidup sebesar 90\% pada perlakuan B dan 93,33\% pada perlakuan C. Murni (2013) melaporkan dari hasil penelitiannya bahwa kombinasi pellet dan maggot sebanyak 50:50 menunjukkan hasil kelangsungan hidup yang lebih baik, karna komninasi kedua jenis pakan tersebut memiliki kandungan nutrisi yang baik dan lengkap sehingga dapat memenuhi kebutuhan nutrisi benih ikan. Sedangkan pada perlakuan D menunjukkan nilai yang paling rendah diduga akibat kandungan nutrisi yang terdapat pada tepung maggot belum mampu memenuhi kebutuhan nutrisi benih ikan patin. Namun demikian, pemanfaatan tepung maggot tidak dapat menggantikan peranan tepung ikan sebagai sumber protein (Newton dan Sheppard, 2005). Sehingga diduga berimbas terhadap kelangsungan hidup benih ikan patin.

\section{Kualitas Air}

Hasil pengamatan kualitas air selama pemeliharaan benih ikan patin dengan pemberian pakan yang ditambahkan tepung maggot ditampilkan pada tabel 5 berikut ini.

Tabel 5. Kualitas air pada pemeliharaan benih ikan patin

\begin{tabular}{lcccc}
\hline \multirow{2}{*}{ Parameter } & \multicolumn{4}{c}{ Perlakuan } \\
\cline { 2 - 5 } Suhu $\left({ }^{\circ} \mathrm{c}\right)$ & $26,5-29,8$ & $26,5-30$ & $\mathbf{C}$ & D \\
\hline pH & $6,9-7,6$ & $7,0-7,8$ & $6,8-30$ & $26,8-29,9$ \\
DO (ppm) & $3,2-4$ & $3,8-4,1$ & $3,7-4,5$ & $7,3-7,6$ \\
Amonia $\left(\mathrm{mg} \mathrm{L}^{-1}\right)$ & $0,012-0,018$ & $0,015-0,024$ & $0,018-0,025$ & $3,1-3,9$ \\
\hline
\end{tabular}

Parameter kualitas air selama penelitian masih dalam batas optimal untuk pemeliharaan ikan patin. Secara keseluruhan nilai kisaran kualitas air mendukung untuk kegiatan pemeliharaan ikan patin, kecuali pada parameter ammonia pada perlakuan B,C, dan D yang berada diatas batas optimum. Ammonia tertinggi terdapat pada perlakuan D yaitu berkisar antara 0,012-0,047 mg/L dimana menurut SNI (2009); Yuli et al., (2017); kadar ammonia yang optimal adalah < 0,01 mg/L. Namun Boyd (1979) mengatakan bahwa kandungan ammonia 
akan bersifat toksik pada konsentrasi 0,6 hingga 2,0 mg/L. Jika dilihat dari data kelangsungan hidup benih ikan patin, maka nilai ammonia yang didapat pada penelitian ini masih menunjukkan nilai yang dapat ditoleransi oleh benih ikan patin. maka dengan kondisi kisaran nilai ammonia selama pemeliharaan tersebut, benih ikan patin masih mampu bertahan. Untuk nilai suhu, masih tergolong suhu optimal untuk menunjang pertumbuhan dan kelangsungan hidup benih ikan patin. Menurut Supriyan et al (2020); Exstrada et al., (2020), nilai suhu yang baik berkisar antara $27-32^{\circ} \mathrm{C}$. Menurut Ramadhan et al (2020), Haris et al., (2018); Haris et al., (2019), biota akuatik menyukai nilai $\mathrm{pH}$ berkisar antara 7 hingga 8,5. Dilihat dari data hasil pengujian $\mathrm{pH}$ selama penelitian maka nilai kualitas air untuk parameter $\mathrm{pH}$ termasuk nilai yang optimal untuk benih ikan patin, sedangkan untuk indikator oksigen terlarut (DO) yang diperoleh selama penelitian termasuk nilai yang optimal menunjang kehidupan benih ikan patin. Hal ini sesuai dengan pendapat Bayumi et a.,l (2021); Wagni et al., (2019); Putri et al., (2019), yang menyatakan bahwa nilai DO yang optimal untuk budidaya ikan patin adalah $2-5 \mathrm{ppm}$.

\section{KESIMPULAN}

Penambahan tepung maggot pada pakan tidak berpengaruh nyata terhadap pertumbuhan, namun memberikan pengaruh nyata terhadap kelangsungan hidup benih ikan patin yang memberikan nilai tertinggi yaitu sebesar $93,3 \%$.

\section{DAFTAR PUSTAKA}

Azir, A., Haris, H., Haris, R.B.K. 2017. Produksi dan Kandungan Nutrisi Maggot (Chrysomya Megacephala) menggunakan Komposisi Media Kultur Berbeda. Jurnal Ilmu - ilmu Perikanan dan Budidaya Perairan. Vol.12 (1): 34-40. Doi 10.31851/jipbp.v12i1.1412.
Bayumi, B., Yusanti, I.A., Anwar, S., Mulyani, R. 2021. Identifikasi Ektoparasit Ikan Patin Siam (Pangasius hypopthalmus) pada Kelompok Pembudidaya Ikan di Sungai Ogan Kabupaten Ogan Ilir. Jurnal Sainmatika. Vol.18(1) : 6875

Boyd, C.E. 1979. Water Quality Management In Fish Pond Culture Aquaculture Experiment Station. Auburn University. Alabama.

Efianda, T.R., Sabirin, S., Islama, D., Mulyani, R. 2020. Pengaruh Pemberian Tepung Kulit Udang Pada Pakan Komersil Terhadap Tingkat Kecerahan Warna Ikan Komet (Carrasius auratus). Jurnal Ilmu-Ilmu Perikanan dan Budidaya Perairan. Vol.15 (2): 133-143. DOI : 10.31851/jipbp.v15i2.5195

Exstrada, F., Yusanti, I. A., Sumantriyadi, S. 2020. Pemberian Pakan Alami Moina sp Dengan Dosis Yang Berbeda Terhadap Pertumbuhan (D3-D21) Larva Ikan Patin Siam (Pangasius hypoptalmus). Jurnal Ilmu-Ilmu Perikanan dan Budidaya Perairan. Vol.15 (2): 105-112

Effendie, I. 1997. Metode Biologi Perikanan. Yayasan Dewi Sri. Bogor

Hanafiah KI. 2002. Rancangan Percobaan. Raja Grafindo Persada. Jakarta

Haris, R.B.K., Yusanti, I.A. 2018. Studi Parameter Fisika Kimia Air Untuk Keramba Jaring Apung Di Kecamatan Sirah Pulau Padang Kabupaten Ogan Komering Ilir Provinsi Sumatera Selatan. Jurnal Ilmu-ilmu Perikanan dan Budidaya Perairan. Vol.14(2). Hlm : 57-62. DOI: 
http://dx.doi.org/10.31851/jipbp. v13i2.2434

Haris, R.B.K., Yusanti, I.A. 2019. Analisis Kesesuaian Perairan Untuk Keramba Jaring Apung Di Kecamatan Sirah Pulau Padang Kabupaten Ogan Komering Ilir Provinsi Sumatera Selatan. Jurnal Lahan Suboptimal. Vol. 8 (1). Hlm : 20-30.

DOI: https://doi.org/10.33230/JLSO.8. 1.2019 .356

Indarmawan. 2014. Hewan Avertebrata Sebagai Pakan Ikan Lele. Fakultas Biologi Universitas Jenderal Soedirman. Purwokerto.

Kardana, D., Haetami, K., Subhan, U. 2012. Efektivitas Penambahan Tepung Maggot Dalam Pakan Komersil Terhadap Pertumbuhan Benih Ikan Bawal Air Tawar (Colosoma macropomum). Jurnal Perikanan dan Kelautan. Vol.3 (4): 177-184.

[KKP] Kementrian Kelautan dan Perikanan. 2016. Subsektor Perikanan Budidaya Sepanjang Tahun 2016 Menunjukkan Kinerja Positif. Sesditjen.

Murni. 2013. Optimasi pemberian kombinasi maggot dengan pakan buatan terhadap pertumbuhan dan sanitasi ikan nila (Oreochromis niloticus). Octopus Jurnal Ilmu Perikanan. Vol.2(2): 192-198.

Mutjiman, A. 2012. Makanan Ikan Penebar Swadaya. Jakarta. 100-151.

Newton, L., Sheppard, Atson, D.W., Burtle, G., \& Dove, R. 2005. Using the Black Soldier fly, Hermitia illucens, as a value-added tool for the management of swine manure.
Reprot for The Animal and Poultry Waste Management Center, 17.

[SNI] Standar Nasional Indonesia. 2009. Ikan Patin Djambal produksi kelas pembesaran di kolam. SNI 7471.5:2009.

Priyadi A, Azwar ZI, Subamia IW, Hem S. 2008. Pemanfaatan maggot sebagai pengganti tepung ikan dalam pakan buatan untuk benih ikan balashark (Balanthiocheilus melanopterus Bleeker). Jurnal Riset Akuakultur. Vol.3 : 367-375.

Putri, W.R., Harris, H., dan Rangga Bayu Kusuma Haris, R.B.K. 2019. Kombinasi maggot pada pakan komersil terhadap pertumbuhan, kelangsungan hidup, FCR dan Biaya Pakan Ikan Patin Siam (Pangasius Hypophthalmus). Jurnal Ilmu-Ilmu Perikanan dan Budidaya Perairan. Vol.14(1) : 7-16

Ramadhan., dan Yusanti, I. A. (2020). Studi Kadar Nitrat Dan Fosfat Perairan Rawa Banjiran Desa Sedang Kecamatan Suak Tapeh Kabupaten Banyuasin. Jurnal Ilmu-ilmu Perikanan dan Budidaya Perairan. Vol.15 No.1. hlm 37-41. DOI

http://dx.doi.org/10.31851/jipbp.v $15 \mathrm{i} 1.4407$

Supriyan, H., Harris, H., Haris, R. B. K., Yusanti, I. A., Sumantriyadi., Arumwati. 2020. Penambahan Probiotik Microbacter Alfaafa 11 TerhadapPertumbuhan,

Kelangsungan Hidup Dan FCR Pada Benih Ikan Patin Siam (Pangasius hypophthalmus). Aurelia Journal. Vol.1 No.2. Hlm : 39-52.

Wangni, G.P., Prayogo, S., Sumantriyadi, S. 2019. Kelangsungan Hidup Dan 
Pertumbuhan Benih Ikan Patin Siam (Pangasius Hypophthalmus) Pada Suhu Media Pemeliharaan Yang Berbeda. Jurnal Ilmu - ilmu Perikanan dan Budidaya Perairan. Vol.14(2) : 21-28.

Wijayanti, M. Nofyan. E dan Handayani. I. 2014. Optimasi Tingkat Pemberian Pakan Buatan terhadap Pertumbuhan dan Kelangsunga Hidup Ikan Patin Jambal (Pangasius djambal). Jurnal Akuakkultur Rawa Indonesia. 2 (2) : 175-187.

Yuli, S., Harris, H., Yusanti, I. A. 2017. Tingkat Serangan Ektoparasit pada Ikan Patin (Pangasius hypopthalmus) yang Dibudidayakan dalam Keramba Jaring Apung di Sungai Musi Palembang. Jurnal Ilmu - ilmu Perikanan dan Budidaya Perairan. Vol.12(2) : 50-58. DOI : http://dx.doi.org/10.31851/jipbp.v1 $2 \mathrm{i} 2.1473$
Yuliansyah WN, Sumantriyadi, Anwar R, Mulyani R. 2021. Efektivitas pertumbuhan ikan Sumatera (Puntius tetrazona) melalui pendekatan ketiggian air media pemeliharaan. Jurnal Ilmu-Ilmu Perikanan dan Budidaya Perairan. Vol.16 (1): 30-40. Doi 10.31851/jipbp.v16i1.5876

Yulisman dan Sasanti.D. A. 2012. Pertumbuhan dan Kelangsungan Hidup Benih Ikan Gabus (Channa striata) yang diberikan Pakan Buatan Berbahan Baku Tepung Keong Emas (Pomacea sp). Jurnal Lahan Suboptimal. Vol.1 (2) : 158162.

Zainudin, Djawad MI, Ardiyanti R. 2012. Pengaruh level protein pakan terhadap laju metabolism juwana ikan bandeng (Chanos chanos). Jurnal Iktiologi Indonesia. Vol.12(2):111-119. 